\title{
THE COMPARATIVE ANALYSIS ON THE OVERVIEW OF HAIR GOAT BREEDINGS TO SUSTAINABLE FOREST RESOURCES MANAGEMENT
}

\author{
KASIKCI, D. ${ }^{1 *}-$ TURKOGLU, T. ${ }^{2}-$ BeKIROGLU, S. $^{3}-$ OZMIS, M. ${ }^{4}-$ TOLUNAY, A. ${ }^{4}$ \\ ${ }^{1}$ Department of Animal Science, Faculty of Agriculture, Isparta University of Applied Sciences, \\ 32260 Isparta, Turkey \\ ${ }^{2}$ Department of Forestry, Koycegiz Vocational School, Mugla Sitki Kocman University, Mugla, \\ Turkey \\ ${ }^{3}$ Department of Forest Engineering, Faculty of Forestry, Istanbul University, Istanbul, Turkey \\ ${ }^{4}$ Department of Forest Engineering, Faculty of Forestry, Isparta University of Applied Sciences, \\ 32260 Isparta, Turkey \\ *Corresponding author \\ e-mail: duygukasikci@isparta.edu.tr; phone: +90-246-211-8584; fax: +90-246-211-8696
}

(Received 22 $2^{\text {nd }} \mathrm{Feb} 2019$; accepted $10^{\text {th }} \mathrm{Apr} 2019$ )

\begin{abstract}
Goat breedings in Turkey is a traditional profession dating back centuries which is carried out in and around forests of rural regions. The purpose of this study was to determine the factors with an impact on sustainable natural resource management based on the opinions of goat breeders and to put forth the contributions that may be provided to establish a sustainable management. The study will contribute to establishing a sustainable goat breeding system in Turkey as well as the management of sustainable forest resources. In this scope, the study was carried out in two different areas in the Mediterranean region of Turkey where goat breeding is widespread. The opinions of goat breeders on demographics, socioeconomic, hair goat breeding and sustainable forest resources management were acquired via survey method and used as the primary data of the study. Descriptive statistics such as frequency, percentage and crosstab values along with Mann-Whitney U Test, Chi-Square Test of Independence and Multivariate Linear Regression Analysis were used as the method. It was determined based on the study results that grazing in forest area is the most important problem for goat breeders and various other problems were also observed related to cooperation with the forest administration. It was observed that goat breeding is carried out via traditional methods by families that are above middle age. The findings indicate that the number of goat breeders decrease as a result of increasing age due to interventions for preventing damages given to trees in the forest by goats during grazing, decrease in the education level and the duration of experience in this profession.
\end{abstract}

Keywords: traditional goat breeding, sustainability, goat-grazing damages

\section{Introduction}

People in rural areas have used their natural resources (agricultural areas, forests, pastures, water sources, etc.) by way of implementing the methods they have learned from their ancestors. These methods of production have been criticized and abandoned with the advent of methods aimed at cheaper mass production in agriculture. However, there is increasing concern with regard to the implications of the widely used modern production methods such as environmental pollution and prevention of the sustainability of ecosystems etc. Therefore, traditional land use methods which do not pollute the environment and which prevent loss of soil were re-evaluated and combined under the concept of agroforestry (Gholz, 1986; Ocak et al., 2007; Tolunay et al., 2002). 
There is an increasing interest in sustainable agriculture defined as the preservation and management of the natural resources for meeting the demands of current and future generations at the highest possible level (Schmincke, 1995; Heitschmidt et al., 1987, 1993; Semerci and Çelik, 2016). Sustainable agriculture is a system used for the production of organic substances that does not pollute the agriculture, soil and water resources with pollutants, that minimizes energy consumption while protecting animal species and the environment (Ocak et al., 2010). Because sustainability with regard to the use of natural resources has gained significant importance due to increasing population and energy demand. In this context, goats bred at high elevations have unique skills in using pastures, rangelands and crop residue as well as the side products in the ecosystem and to transform these into food. Thanks to these skills, it is easier to feed the goats that have adapted to high elevation areas. Based on this knowledge, local people living at areas of high elevation have earned their living for centuries by breeding animals by using such traditional methods (Aldezabal and Garin, 2000; Ainalis and Tsiouvaras, 2004; Ainalis et al., 2006; Zarovali et al., 2007).

It is known that traditional land use methods are mostly applied by rural populations in underdeveloped or developing countries. Because majority of these people live far away from modern education opportunities and acquire their knowledge on earning a living and life in general from the information passed down to them by their ancestors. In addition, the importance given to traditional production methods has increased in our day resulting in increased support to such methods. In this scope, traditional goat and hair goat breeding that makes use of mountainous and unfertile rangelands in marginal lands of rural areas are among the activities that stand out (Ocak et al., 2007). Of these, hair goat breeding attracts attention as a form of cultural life in addition to being a unique economical production system (Güney and Darcan, 2005). The relation between socioeconomic, cultural, and recreational needs of the pastoral people and goat breeding is an undeniable reality (Kıvrak, 2014; Bekiroğlu et al., 2016).

The hair goat breeding areas in Europe are located within the borders where certain tree and shrub species considered among Mediterranean scrub vegetation are distributed. It has been determined that Kermes oak (Qercus coccifera L.) and Holm oak (Qercus ilex L.) species the leaves of which are preferred by hair goats can be found frequently in these areas (Ainalis et al., 2006; Zarovali et al., 2007; Tolunay et al., 2002; Tolunay et al., 2009; Tasligil and Sahin, 2010). Thus, it is accepted that the hair goat population living areas in the Mediterranean region overlap with the areas where these two tree species are naturally distributed. However, grazing bans have been imposed for hair goat owners in state forests where these two tree species are distributed since it is indicated that the goats damage the trees of the forests. Moreover, hair goat breeding villagers have been forced to put an end to their adopted cultural ways of life. Therefore, the hair goat population in the Mediterranean Region has declined drastically (Ince et al., 2009; Ince, 2010; Güney and Darcan, 2005). In addition, the tendency for natural and organic nutrition has increased in recent years resulting in an increased demand in products produced in completely natural environments (Morand-Fehr et al., 2004; Boyazoglu et al., 2005). In line with this tendency, natural products obtained from animals raised at high elevations have started to be preferred more by consumers. Because it has been proven scientifically that the cholesterol and protein values of these animal products (meat, milk, fat, cheese etc.) are superior in comparison with those obtained from other environments of production (Koyuncu and Tuncel, 2010; Laugesen et al., 2003). Indeed, the plant diversity of meadows and rangelands at high elevations is 
higher in comparison with others and the plants that grow on these areas have higher nutritive values. Moreover, industrial activities decrease with increasing elevation resulting in less environmental pollution in such areas. In conclusion, natural environments at high elevation that are not damaged by people have recently started to become centers of attraction as quality grazing areas for animal breeding. As a result, hair goats that have provided natural products such as wool, milk, meat, horn to the breeding local public started to gain importance as a popular economic commodity and the relationship between hair goat-ecosystem has been subject to re-evaluations. Recent scientific studies have shown that hair goats are not actually enemies of the forest as was considered previously but are animals that support the sustainability of the current ecosystem. As a result of this development, countries in the Mediterranean Region are trying to develop traditional goat breeding systems at the distribution areas of especially the Kermes oak (Qercus coccifera L.) and Holm oak (Qercus ilex L.) species (Aldezabal and Garin, 2000; Ainalis and Tsiouvaras, 2004; Ainalis et al., 2006; Zarovali et al., 2007).

Turkey is one of the countries where the rural population carries out hair goat breeding traditionally and culturally. It is known that hair goat breeding is carried out for thousands of years on a wide geographical area stretching out in south and southeastern Turkey. The hair goat population was decreased in this country by applying the "Hair goat Action Plan" on the basis of the opinion that hair goats are among the animals that harm forests the most thereby resulting in the narrowing down of areas where these animals are bred. However, there is still a certain rural population that insists on sustaining the traditional way of life based on a breeding despite all the imposed sanctions. Isparta is one of the cities where majority of this rural population lives (Fig. 2). However, hair goat breeders in the city of Isparta have not yet started to benefit from the positive atmosphere resulting from the increased organic nutrition demand and the global importance given to traditional methods of production. In addition, the breeding of hair goats adopted to these areas dates back centuries in Mediterranean forest ecosystems and is receiving continuously increasing support for the as one of the most successful methods of organic animal breeding (Ince and Karaca, 2009; Ince et al., 2009; Koknaroglu et al., 2007; Basullu and Tolunay, 2010).

The aim of this study was to determine the opinions of breeders at two study areas that have similar demographic, socioeconomic and geographical conditions in the Isparta region on the improvement of sustainable forest resources, rangeland management and the ecosystem conditions in the region. Factors that impact the sustainability of natural resources were determined based on the opinions of goat breeders living on both study areas in the rural region after which the contributions that can be made for a sustainable management were indicated.

\section{Materials and methods}

\section{Study area}

Merkez and Sutculer districts in the province of Isparta located in the Mediterranean Region of Turkey were selected as the study area (Fig. 1). Because, the city of Isparta is one of the most important cities with regard to traditional hair goat breeding.

The study area is a mountainous region with high elevation (the average elevation of Merkez is $1068 \mathrm{~m}$, and the average elevation of Sutculer is $991 \mathrm{~m}$ ). This is a unique region where air pressure, oxygen amount and climate conditions differ. Therefore, it 
has an impact on all living population in this region. Hair goat breeding is an important means of living that provides income and food safety for the villagers in this region.

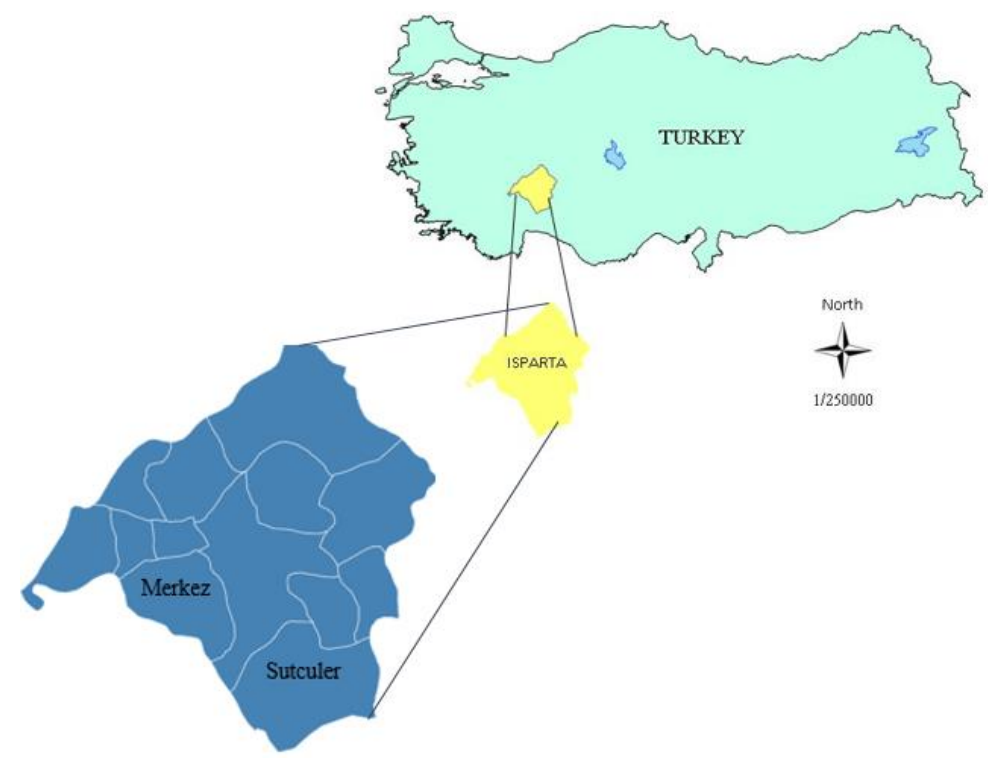

Figure 1. Map of the study area

\section{Materials}

The survey form prepared for obtaining the opinions of goat breeders on sustainable forest resources management was used for data acquisition. The survey form was comprised of 3 questions on the demographic characteristics of goat breeders, 4 questions on their socioeconomic characteristics, 10 questions on hair goat breeding and 13 questions on sustainable forest resource (forest-rangeland) management. The dependent and independent variables of the study are given in Table 1 . There were a total of 180 and 144 goat breeders in the first and second study areas respectively and face to face interviews were carried out with $71(40 \%)$ of the breeders in the first study area and $97(67 \%)$ in the second study area. This sample group is considered as sufficient at a confidence interval of 10\% (Karaasar, 2012; Sample Size Calculator; 2018). The survey was applied during March-August 2018 on randomly selected hair goat breeders aged above 18. The study variables generated based on the survey questions are given in Table 1.

\section{Methods}

Descriptive statistics such as frequency, percentage and crosstab values were used as the method of this study along with Mann-Whitney U Test, Chi-Square Test of Independence and Multivariate Linear Regression Analysis. The demographicsocioeconomic characteristics of Sutculer and Isparta districts breeders as well as their characteristics related with hair goat breeding-sustainable forest management were indicated via frequency and percentage values. Crosstab results were calculated for the "Age" and "Marital Status" characteristics as well as the variables of "Grazing penalty from the Forest Administration", "Cooperation with the Forest Administration" and "Quitting the breeding profession". 
Table 1. The survey questions

\begin{tabular}{|c|c|c|c|}
\hline \multicolumn{3}{|c|}{ Variables } & \multirow{2}{*}{ Marked options } \\
\hline & Definition & Symbol & \\
\hline \multirow{3}{*}{ 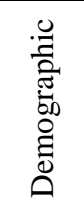 } & Age (year) & $\mathrm{X} 1$ & a) $18-30$, b) $31-42$, c) $43-55$, d) $56-70$ \\
\hline & Marital status & $\mathrm{X} 2$ & a) Single, b) Married, c) Widowed \\
\hline & Education & $\mathrm{X} 3$ & $\begin{array}{l}\text { a) Not Literate, b) Literate, c) Elementary school, } \\
\text { d) Secondary school, e) High school, f) University }\end{array}$ \\
\hline \multirow{4}{*}{ 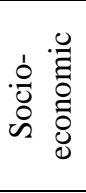 } & Shepherd time (year) & $\mathrm{X} 4$ & a) $<5$, b) $6-10$, c) $11-15$, d) $16-20$, e) $>20$ \\
\hline & Traditionally shepherd & $\mathrm{X} 5$ & a) Yes, b) No \\
\hline & Get help from family other & $\mathrm{X} 6$ & a) Yes, b) No \\
\hline & Other sources of income & $\mathrm{X} 7$ & a) Yes, b) No \\
\hline \multirow{10}{*}{ 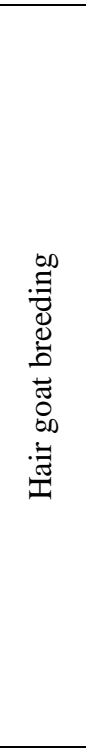 } & \begin{tabular}{|c|} 
The new generation willing to be a \\
shepherd
\end{tabular} & $\mathrm{X} 8$ & a) Yes, b) No, c) Undecided \\
\hline & Having grazing penalty & $\mathrm{X} 9$ & a) Yes, b) No \\
\hline & Altitude of pasturage $(\mathrm{m})$ & $\mathrm{X} 10$ & a) $0-500$, b) $501-800$, c) $801-1200$, d) $>1200$ \\
\hline & Favorite plants of hair goats & $\mathrm{X} 11^{*}$ & $\begin{array}{l}\text { a) Bush, b) Annual plants grown in forest, c) Fresh } \\
\text { exiles of pine trees }\end{array}$ \\
\hline & Goat breeds supported by state & $\mathrm{X} 12^{*}$ & $\begin{array}{l}\text { a) Hair goats, b) Honamli, c) Kilis, d) Tiftik, e) } \\
\text { Others }\end{array}$ \\
\hline & Grazing areas & $\mathrm{X} 13^{*}$ & $\begin{array}{l}\text { a) Any place in the county, b) Rangelands, c) } \\
\text { Forest areas, d) Highlands }\end{array}$ \\
\hline & Ownership of grazing land & $\mathrm{X} 14$ & $\begin{array}{l}\text { a) Forest land, b) I own the land, c) I know the } \\
\text { landowner, d) I do not know the landowner }\end{array}$ \\
\hline & Is the village pasture mismanaged & $\mathrm{X} 15$ & a) Yes, b) No, c) Undecided \\
\hline & $\begin{array}{c}\text { Foreign shepherds should be } \\
\text { allowed grazing }\end{array}$ & $\mathrm{X} 16$ & a) Yes, b) No, c) Undecided \\
\hline & $\begin{array}{c}\text { The most important problem of the } \\
\text { shepherds }\end{array}$ & $\mathrm{X} 17$ & $\begin{array}{l}\text { a) Grazing, b) Low income c) Animal sale, d) } \\
\text { Living condition }\end{array}$ \\
\hline \multirow{13}{*}{ 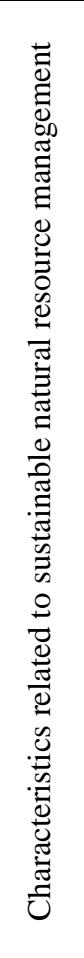 } & \begin{tabular}{|c|}
$\begin{array}{c}\text { Collaborating with the forest } \\
\text { administration }\end{array}$ \\
\end{tabular} & $\mathrm{X} 18$ & a) Yes, b) No, c) Undecided, d) Other \\
\hline & $\begin{array}{l}\text { Request from the Forest } \\
\text { Administration }\end{array}$ & $\mathrm{X} 19$ & $\begin{array}{l}\text { a) Creating pastures, b) Forgiving crimes, c) } \\
\text { Ensuring trust, d) Other }\end{array}$ \\
\hline & Prevention of damage to trees & $\mathrm{X} 20$ & a) Yes, b) No, c) Somewhat, d) Not interested \\
\hline & Prevention of damage to sapling & $\mathrm{X} 21$ & a) Yes, b) No, c) Somewhat, d) Not interested \\
\hline & $\begin{array}{l}\text { Easily overcome fences in forests } \\
\text { by animals }\end{array}$ & $\mathrm{X} 22$ & a) Yes, b) No, c) Undecided \\
\hline & $\begin{array}{l}\text { Barbed wires in forests damage } \\
\text { animals }\end{array}$ & $\mathrm{X} 23$ & a) Yes, b) No, c) Undecided \\
\hline & $\begin{array}{l}\text { Characteristics of the grazing area } \\
\text { to be requested from the forest } \\
\text { administration }\end{array}$ & $\mathrm{X} 24$ & $\begin{array}{l}\text { a) Only me, b) Only give to } 2-3 \text { shepherds, c) Let } \\
\text { grazing permission be given everyone, d) It does } \\
\text { not matter }\end{array}$ \\
\hline & Pasture problem of forest area & $\mathrm{X} 25$ & a) Yes, b) No, c) Undecided \\
\hline & Quitting shepherd profession & $\mathrm{X} 26$ & a) Yes, b) No, c) Seldom, d) Undecided \\
\hline & \begin{tabular}{|c|}
$\begin{array}{c}\text { To want their children to be a } \\
\text { shepherd }\end{array}$ \\
\end{tabular} & $\mathrm{X} 27$ & $\begin{array}{l}\text { a) Yes, b) May be, c) If they cannot find other } \\
\text { jobs, d) Certainly not }\end{array}$ \\
\hline & \begin{tabular}{|c|} 
Raising children's awareness about \\
forest conversation
\end{tabular} & $\mathrm{X} 28$ & a) Yes, b) No, c) Undecided \\
\hline & To planting saplings on forest land & $\mathrm{X} 29$ & a) Yes, b) No, c) Undecided \\
\hline & $\begin{array}{c}\text { To warn people who damage } \\
\text { forests }\end{array}$ & $\mathrm{X} 30$ & a) Yes, b) No, c) Undecided \\
\hline
\end{tabular}

*Multiple options were marked 
Mann-Whitney U Test was used for determining whether there are differences in opinion between the breeders of the two selected districts with regard to the study variables (Table 1). Chi-Square Test of Independence was used for determining if there is any relationship between the demographic-socioeconomic characteristics and hair goat breeding-sustainable natural resource management characteristics for the two districts. In addition, Multivariate Linear Regression Analysis was applied for predicting the variables of "Cooperation with the forest administration (X18)", "Expelling tree-harming animals from the forest (X20)", "Expelling shoot-harming animals from the forest (X21)", "Desiring the children to be breeders (X27), "quitting the breeding profession (X26)" and "Warning people who can harm the forest (X30)". These analyses were carried out via IBM SPSS 22.0 package software and the reliability level during these statistical tests was accepted as $95 \%$.

\section{Results and discussion}

\section{Opinions of goat breeders on demographics, socioeconomics and hair goat breeding and sustainable natural resource management}

Figures 2, 3, 4 and 5 provide an overview on the descriptive statistics related with the demographic, socioeconomic and hair goat breeding and sustainable natural resource management characteristics of breeders in Sutculer and Merkez districts.

As can be seen when the demographic characteristics of the Sutculer and Merkez districts breeders are examined that their age interval is $43-55$ for $37 \%$ of the breeders in Sutculer and 36\% in Merkez districts (Fig. 2). About 30\% of all breeders in both study areas were above the age of 55. It is observed that the desire of the new generation to work as breeders was slightly higher in the Sutculer district (51\%) in comparison with Merkez district (Fig. 2). Goat breeding is not a preferred profession among the young population in Turkey (Guney and Darcan, 2001). Hence, the concept of "Herd Manager" was tried to be integrated instead of the term "breeder" but to no avail. Recently, goat breeders in Turkey employ breeders from foreign countries such as Afghanistan, Pakistan and Syria (Tolunay et al., 2018).

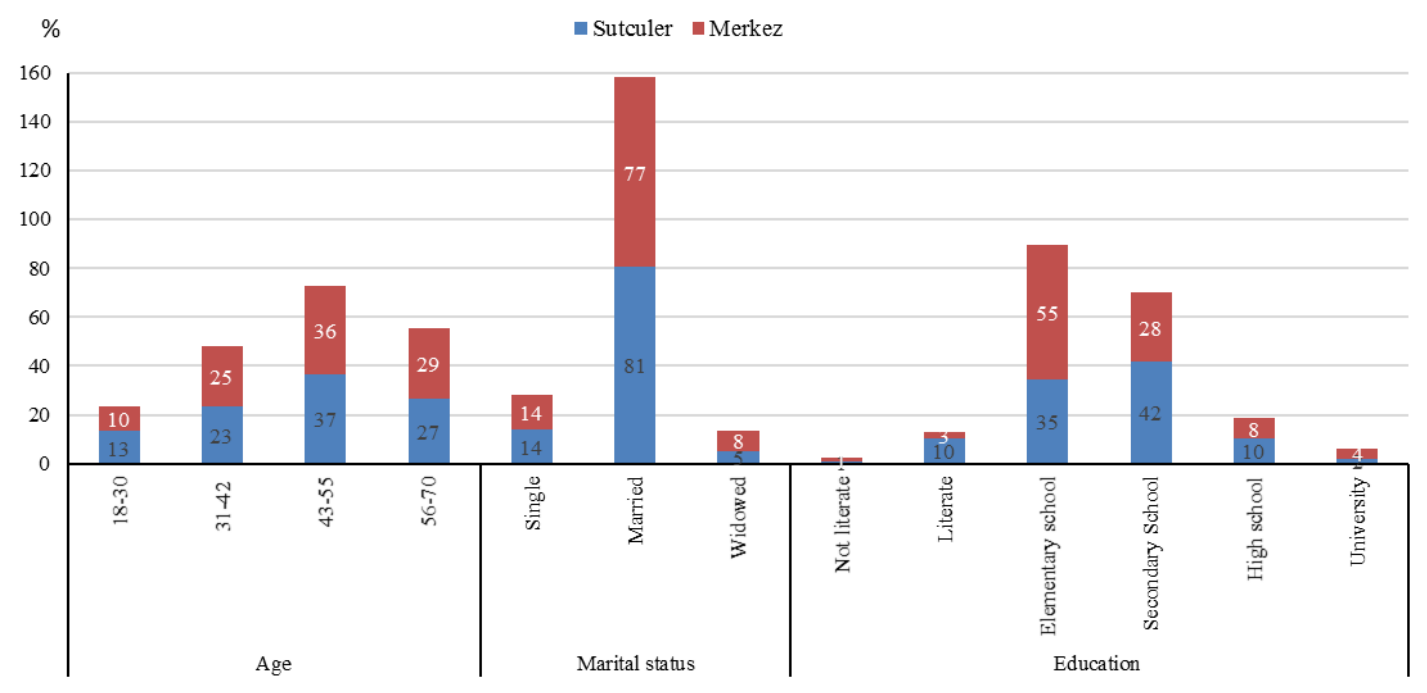

Figure 2. Demographic characteristics of the samples 
It was observed that $81 \%$ of the goat breeders who participated in the study were married, while this ratio for the Merkez district was $77 \%$. Of the breeders in both study areas, 84-93\% continues this profession together with their family members (Fig. 2). Goat breeding in Turkey is a family profession (Arac and Daskiran, 2010). If we consider the levels of education, 55\% in Merkez district were primary school graduates, whereas $42 \%$ in Sutculer district were secondary school graduates. The education level of goat breeders is generally low. The reasons for this can be indicated as nomadic life in rural areas, the distance of rangelands to areas of settlement as well as the fact that breeding is a full time profession (Ince et al., 2009).

Of the breeders, $73 \%$ in Sutculer and 59\% in Merkez districts have been working in this profession for over 20 years. It was indicated by $96 \%$ of the breeders in Sutculer district, and $89 \%$ in Merkez district that they are continuing this profession based on traditional methods (Fig. 3). Traditional breeding is a unique form of breeding that is mostly based on methods passed down from earlier generations for which a style specific to the related region is adopted with positive impacts on the economy and handcrafts by way of different animal based products. It is of significant importance since these primeval traditions reflect the socio-cultural and economical lives of the local public.

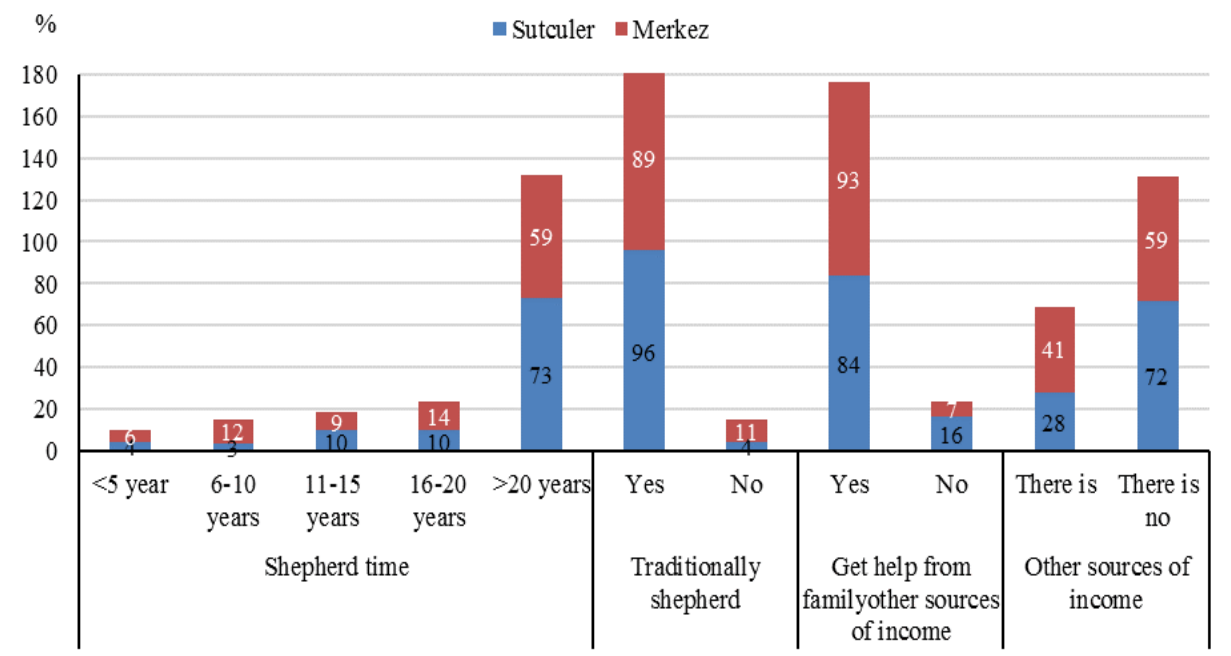

Figure 3. Socio-economics characteristics of the samples

When examined with regard to hair goat breeding characteristics, the most important problems that breeders face were grazing in Merkez district (39\%) and low income in Sutculer district (55\%). Grazing permit to foreign breeders was 83\% in Merkez and $63 \%$ in Sutculer (Fig. 4). Hair goat breeding in Turkey is completely based on Forests and Forest rangelands. Other animal breeding activities either cannot be carried out in these areas due to environmental conditions or they can be carried out at minimum levels. Forests are legally allocated areas for hair goat breeding. However, "Grazing Regulation" has prohibited the grazing of hair goats in forests. The Forest Administration has filed lawsuits against individuals grazing hair goats in state forests based on the provisions of this regulation. Individuals convicted by judicial authorities were subject to fines and prison terms. Rangeland issue is still waiting to be solved as the most important problem of goat breeders (Tolunay et al., 2015). 


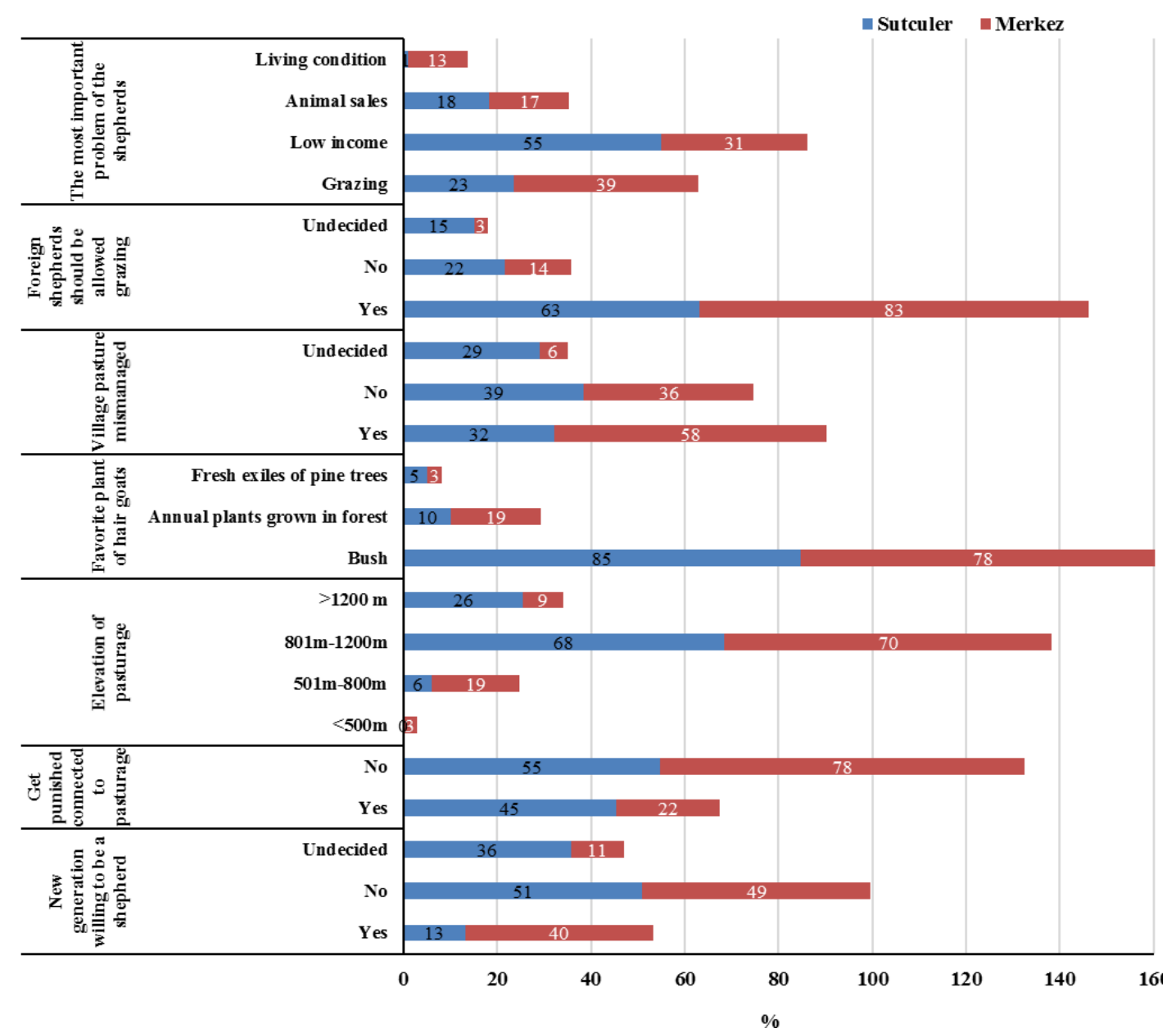

Figure 4. Characteristics related to hair goat breeding of samples

The fact that rangelands in Turkey are small and fragmented results in overgrazing pressure. Rangeland and Grazing are still issues waiting to be solved due to reasons such as the lack of planned grazing, excessive damages due to off-season grazing and overgrazing, failure to protect the rangeland borders, infrastructure problems of Rangeland Management Associations, general decisions on Grazing Period (Kaşıkcı et al., 2016).

Of the breeders, $58 \%$ are of the opinion that village headmen in Sutculer implement erroneous management with regard to rangelands. This ratio is $32 \%$ in Merkez District and is lower. Kermes oak and other shrubbery making up the Mediterranean scrubs were indicated in both groups as food preferred by the goats $(85 \%, 78 \%)$. The goats are grazed at elevations ranging between $801-1200 \mathrm{~m}$ in both groups. Especially in the Sutculer District, $55 \%$ of the breeders were fined by the Forest Administration. Goat breeds of Turkey have been supported by Ministry of Agriculture and Forestry in Turkey. In the study areas, $65 \%$ of goat breedings are supported by the state for hair goat breeding, $17 \%$ of the others are for Honamli goat, $14 \%$ for Kilis goat and $4 \%$ of the other breeds. Goats are grazed in 35\% mountain areas (around of forest areas), 30\% in pastures, $24 \%$ in highlands and $11 \%$ in other fields.

It attracts attention that there both groups are sensitive with regard to warning those who harm the forests. It is striking that the children of breeders in both groups are 
conscious with regard to the protection of forests. A very little portion of the breeders want their children to be breeders. Of the breeders, $79 \%$ in Sutculer district and $64 \%$ in Merkez district indicated the need for new grazing areas. $75 \%$ of the breeders stated that there is no pasture in forest areas or around the forest (Fig. 5). It is also understood that the breeders are sensitive with regard to the prevention of harming the trees.

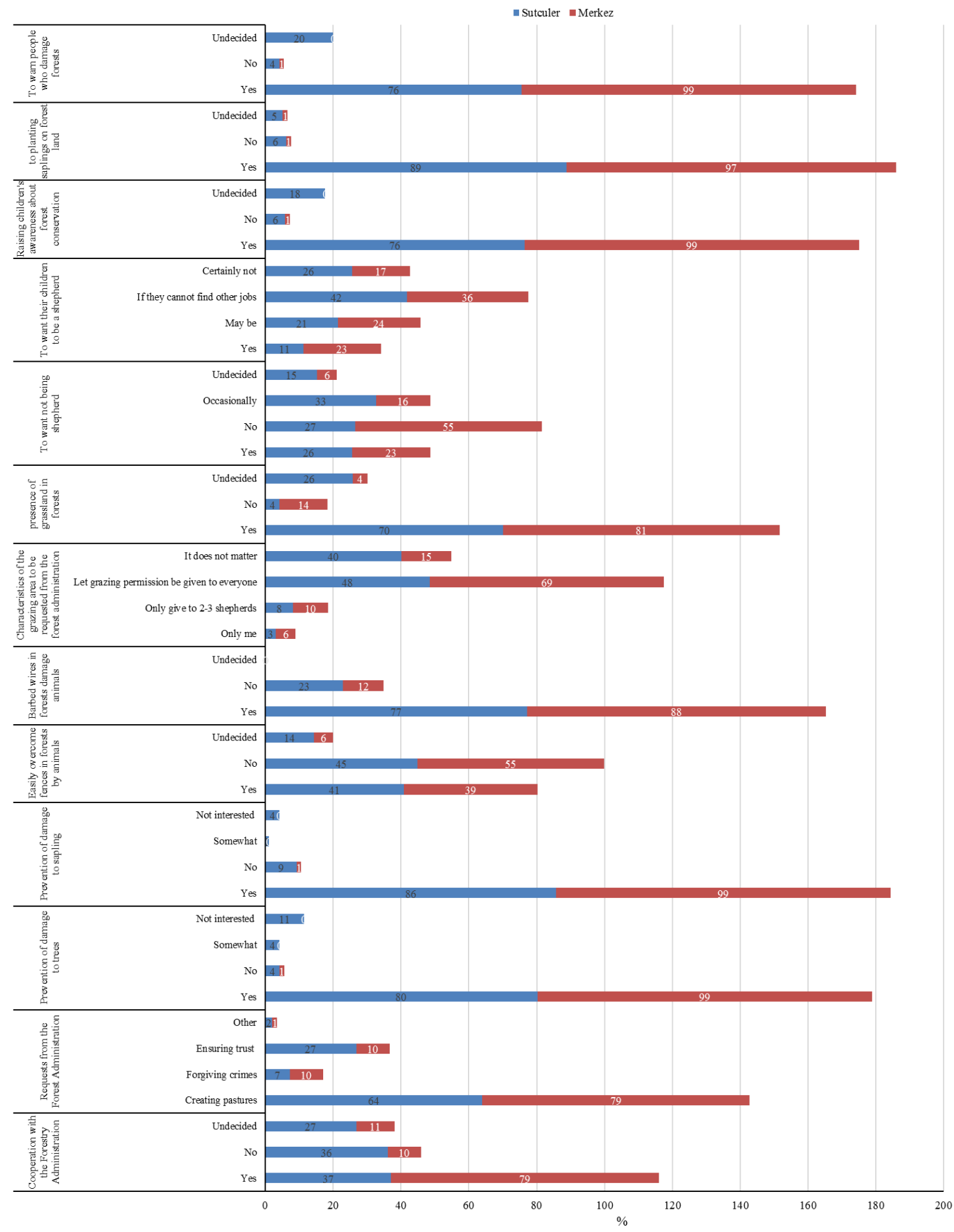

Figure 5. Characteristics related to sustainable natural resource management of samples 


\section{Examination of the impacts of the age and marital status of goat breeders on the management of sustainable forest resources}

Crosstab results were calculated for the relation between the "Age" and "Marital status" characteristics of breeders in Sutculer and Isparta and the variables of "Grazing penalty from the Forest Administration", "Cooperation with the Forest Administration" and "Quitting the breeding profession" (Tables 2 and 3).

Table 2. Cross tabulation results of Sutculer district

\begin{tabular}{|c|c|c|c|c|c|c|c|c|c|c|c|c|c|c|}
\hline & \multicolumn{2}{|c|}{$\begin{array}{l}\text { Having grazing } \\
\text { penalty }\end{array}$} & \multirow{2}{*}{ Total } & \multicolumn{3}{|c|}{$\begin{array}{c}\text { Collaborating with the forest } \\
\text { administration }\end{array}$} & \multirow{2}{*}{ Total } & \multicolumn{4}{|c|}{ Quitting shepherd profession } & \multirow{2}{*}{ Total } \\
\hline & & & Yes & No & & Yes & No & Undecided & & Yes & No & Seldom & Undecided & \\
\hline \multirow{10}{*}{$\stackrel{8}{<}$} & \multirow{2}{*}{$18-30$} & Count & 7 & 6 & 13 & 3 & 6 & 4 & 13 & 6 & 1 & 4 & 2 & 13 \\
\hline & & $\%$ within $X_{\mathrm{i}}$ & $15.9 \%$ & $11.3 \%$ & $13.4 \%$ & $8.3 \%$ & $17.1 \%$ & $15.4 \%$ & $13.4 \%$ & $24.0 \%$ & $3.8 \%$ & $12.5 \%$ & $13.3 \%$ & $13.3 \%$ \\
\hline & \multirow{2}{*}{$31-42$} & Count & 11 & 12 & 23 & 7 & 11 & 5 & 23 & 6 & 8 & 6 & 3 & 23 \\
\hline & & $\%$ within $\mathrm{X}_{\mathrm{i}}$ & $25.0 \%$ & $22.6 \%$ & $23.7 \%$ & $19.4 \%$ & $31.4 \%$ & $19.2 \%$ & $23.7 \%$ & $24.0 \%$ & $30.8 \%$ & $18.8 \%$ & $20.0 \%$ & $23.5 \%$ \\
\hline & \multirow{2}{*}{$43-55$} & Count & 15 & 20 & 35 & 15 & 11 & 10 & 36 & 8 & 11 & 11 & 6 & 36 \\
\hline & & $\%$ within $\mathrm{X}_{\mathrm{i}}$ & $34.1 \%$ & $37.7 \%$ & $36.1 \%$ & $41.7 \%$ & $31.4 \%$ & $38.5 \%$ & $37.1 \%$ & $32.0 \%$ & $42.3 \%$ & $34.4 \%$ & $40.0 \%$ & $36.7 \%$ \\
\hline & \multirow{2}{*}{$56-70$} & Count & 11 & 15 & 26 & 11 & 7 & 7 & 25 & 5 & 6 & 11 & 4 & 26 \\
\hline & & $\%$ within $\mathrm{X}_{\mathrm{i}}$ & $25.0 \%$ & $28.3 \%$ & $26.8 \%$ & $30.6 \%$ & $20.0 \%$ & $26.9 \%$ & $25.8 \%$ & $20.0 \%$ & $23.1 \%$ & $34.4 \%$ & $26.7 \%$ & $26.5 \%$ \\
\hline & \multirow{2}{*}{ Total } & Count & 44 & 53 & 97 & 36 & 35 & 26 & 97 & 25 & 26 & 32 & 15 & 98 \\
\hline & & $\%$ within $X_{i}$ & $100.0 \%$ & $100.0 \%$ & $100.0 \%$ & $100.0 \%$ & $100.0 \%$ & $100.0 \%$ & $100.0 \%$ & $100.0 \%$ & $100.0 \%$ & $100.0 \%$ & $100.0 \%$ & $100.0 \%$ \\
\hline \multirow{8}{*}{ 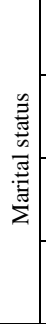 } & \multirow{2}{*}{ Single } & Count & 8 & 6 & 14 & 4 & 7 & 3 & 14 & 6 & 1 & 5 & 2 & 14 \\
\hline & & $\%$ within $X_{i}$ & $18.2 \%$ & $11.3 \%$ & $14.4 \%$ & $11.1 \%$ & $20.0 \%$ & $11.5 \%$ & $14.4 \%$ & $24.0 \%$ & $3.8 \%$ & $15.6 \%$ & $13.3 \%$ & $14.3 \%$ \\
\hline & \multirow{2}{*}{ Married } & Count & 33 & 45 & 78 & 30 & 26 & 22 & 78 & 18 & 23 & 26 & 12 & 79 \\
\hline & & $\%$ within $\mathrm{X}_{\mathrm{i}}$ & $75.0 \%$ & $84.9 \%$ & $80.4 \%$ & $83.3 \%$ & $74.3 \%$ & $84.6 \%$ & $80.4 \%$ & $72.0 \%$ & $88.5 \%$ & $81.3 \%$ & $80.0 \%$ & $80.6 \%$ \\
\hline & \multirow{2}{*}{ Other } & Count & 3 & 2 & 5 & 2 & 2 & 1 & 5 & 1 & 2 & 1 & 1 & 5 \\
\hline & & $\%$ within $X_{i}$ & $6.8 \%$ & $3.8 \%$ & $5.2 \%$ & $5.6 \%$ & $5.7 \%$ & $3.8 \%$ & $5.2 \%$ & $4.0 \%$ & $7.7 \%$ & $3.1 \%$ & $6.7 \%$ & $5.1 \%$ \\
\hline & \multirow{2}{*}{ Total } & Count & 44 & 53 & 97 & 36 & 35 & 26 & 97 & 25 & 26 & 32 & 15 & 98 \\
\hline & & $\%$ within $\mathrm{Xi}$ & $100.0 \%$ & $100.0 \%$ & $100.0 \%$ & $100.0 \%$ & $100.0 \%$ & $100.0 \%$ & $100.0 \%$ & $100.0 \%$ & $100.0 \%$ & $100.0 \%$ & $100.0 \%$ & $100.0 \%$ \\
\hline
\end{tabular}

$\mathrm{X}_{\mathrm{i}}$ : having grazing penalty, collaborating with the forest administration, quitting shepherd profession

Table 3. Cross tabulation results of Merkez district

\begin{tabular}{|c|c|c|c|c|c|c|c|c|c|c|c|c|c|c|c|}
\hline & & & \multicolumn{2}{|c|}{$\begin{array}{c}\text { Having grazing } \\
\text { penalty }\end{array}$} & \multirow{2}{*}{ Total } & \multicolumn{4}{|c|}{$\begin{array}{c}\text { Collaborating with the forest } \\
\text { administration }\end{array}$} & \multirow{2}{*}{ Total } & \multicolumn{4}{|c|}{ Quitting shepherd profession } & \multirow{2}{*}{ Total } \\
\hline & & & Yes & No & & Yes & No & Undecided & Other & & Yes & No & Seldom & Undecided & \\
\hline \multirow{5}{*}{$\stackrel{\infty}{\&}$} & $18-30$ & $\begin{array}{c}\text { Count } \\
\% \text { within } \mathrm{X}_{\mathrm{i}}\end{array}$ & $\begin{array}{c}1 \\
6.7 \% \\
\end{array}$ & $\begin{array}{c}6 \\
11.3 \% \\
\end{array}$ & $\begin{array}{c}7 \\
10.0 \% \\
\end{array}$ & $\begin{array}{c}5 \\
9.1 \% \\
\end{array}$ & $\begin{array}{c}1 \\
14.3 \% \\
\end{array}$ & $\begin{array}{c}1 \\
14.3 \% \\
\end{array}$ & $\begin{array}{c}0 \\
.0 \% \\
\end{array}$ & $\begin{array}{c}7 \\
10.0 \% \\
\end{array}$ & $\begin{array}{c}2 \\
12.5 \% \\
\end{array}$ & $\begin{array}{c}4 \\
10.5 \% \\
\end{array}$ & $\begin{array}{c}1 \\
9.1 \% \\
\end{array}$ & $\begin{array}{c}0 \\
.0 \% \\
\end{array}$ & $\begin{array}{c}7 \\
10.1 \% \\
\end{array}$ \\
\hline & $31-42$ & $\begin{array}{c}\text { Count } \\
\text { \% within } \mathrm{X}_{\mathrm{i}}\end{array}$ & $\begin{array}{c}6 \\
40.0 \%\end{array}$ & $\begin{array}{c}11 \\
20.8 \%\end{array}$ & $\begin{array}{c}17 \\
24.3 \%\end{array}$ & $\begin{array}{c}14 \\
25.5 \%\end{array}$ & $\begin{array}{c}3 \\
42.9 \%\end{array}$ & $\begin{array}{c}0 \\
.0 \%\end{array}$ & $\begin{array}{c}0 \\
.0 \%\end{array}$ & $\begin{array}{c}17 \\
24.3 \%\end{array}$ & $\begin{array}{c}4 \\
25.0 \%\end{array}$ & $\begin{array}{c}6 \\
15.8 \%\end{array}$ & $\begin{array}{c}5 \\
45.5 \%\end{array}$ & $\begin{array}{c}1 \\
25.0 \%\end{array}$ & $\begin{array}{c}16 \\
23.2 \%\end{array}$ \\
\hline & $43-55$ & $\begin{array}{c}\text { Count } \\
\text { \% within } \mathrm{X}_{\mathrm{i}}\end{array}$ & $\begin{array}{c}5 \\
33.3 \%\end{array}$ & $\begin{array}{c}19 \\
35.8 \%\end{array}$ & $\begin{array}{c}25 \\
35.7 \%\end{array}$ & $\begin{array}{c}20 \\
36.4 \%\end{array}$ & $\begin{array}{c}1 \\
14.3 \%\end{array}$ & $\begin{array}{c}3 \\
42.9 \%\end{array}$ & $\begin{array}{c}1 \\
100 \%\end{array}$ & $\begin{array}{c}25 \\
35.7 \%\end{array}$ & $\begin{array}{c}6 \\
37.5 \%\end{array}$ & $\begin{array}{c}12 \\
31.6 \%\end{array}$ & $\begin{array}{c}4 \\
36.4 \%\end{array}$ & $\begin{array}{c}3 \\
75.0 \%\end{array}$ & $\begin{array}{c}25 \\
36.2 \%\end{array}$ \\
\hline & $56-70$ & $\begin{array}{c}\text { Count } \\
\% \text { within } \mathrm{X}_{\mathrm{i}}\end{array}$ & $\begin{array}{c}3 \\
20.0 \%\end{array}$ & $\begin{array}{c}17 \\
32.1 \%\end{array}$ & $\begin{array}{c}21 \\
30 \% \\
\end{array}$ & $\begin{array}{c}16 \\
29.1 \%\end{array}$ & $\begin{array}{c}2 \\
28.6 \%\end{array}$ & $\begin{array}{c}3 \\
42.9 \%\end{array}$ & $\begin{array}{c}0 \\
.0 \%\end{array}$ & $\begin{array}{c}21 \\
30 \%\end{array}$ & $\begin{array}{c}4 \\
25.0 \%\end{array}$ & $\begin{array}{c}16 \\
42.1 \%\end{array}$ & $\begin{array}{c}1 \\
9.1 \% \\
\end{array}$ & $\begin{array}{c}0 \\
.0 \%\end{array}$ & $\begin{array}{c}21 \\
30.4 \% \\
\end{array}$ \\
\hline & Total & $\begin{array}{c}\text { Count } \\
\text { \% within } \mathrm{X}_{\mathrm{i}}\end{array}$ & $\begin{array}{c}15 \\
100 \%\end{array}$ & $\begin{array}{c}53 \\
100 \%\end{array}$ & $\begin{array}{c}70 \\
100 \%\end{array}$ & $\begin{array}{c}55 \\
100 \%\end{array}$ & $\begin{array}{c}7 \\
100 \%\end{array}$ & $\begin{array}{c}7 \\
100 \%\end{array}$ & $\begin{array}{c}1 \\
100 \%\end{array}$ & $\begin{array}{c}70 \\
100 \%\end{array}$ & $\begin{array}{c}16 \\
100 \%\end{array}$ & $\begin{array}{c}38 \\
100 \%\end{array}$ & $\begin{array}{c}11 \\
100 \%\end{array}$ & $\begin{array}{c}4 \\
100 \%\end{array}$ & $\begin{array}{c}69 \\
100 \% \\
\end{array}$ \\
\hline \multirow{3}{*}{ 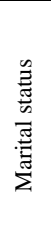 } & Single & $\begin{array}{c}\text { Count } \\
\text { \% within } \mathrm{X}_{\mathrm{i}}\end{array}$ & $\begin{array}{c}1 \\
7.7 \% \\
\end{array}$ & $\begin{array}{c}8 \\
16.3 \%\end{array}$ & $\begin{array}{c}9 \\
14.1 \%\end{array}$ & $\begin{array}{c}8 \\
16.0 \%\end{array}$ & $\begin{array}{c}1 \\
14.3 \%\end{array}$ & $\begin{array}{c}1 \\
14.3 \%\end{array}$ & $\begin{array}{c}0 \\
.0 \%\end{array}$ & $\begin{array}{c}10 \\
15.4 \%\end{array}$ & $\begin{array}{c}3 \\
20.0 \%\end{array}$ & $\begin{array}{c}3 \\
8.6 \%\end{array}$ & $\begin{array}{c}3 \\
33.3 \%\end{array}$ & $\begin{array}{c}0 \\
.0 \%\end{array}$ & $\begin{array}{c}9 \\
14.3 \%\end{array}$ \\
\hline & Married & $\begin{array}{c}\text { Count } \\
\text { \% within } \mathrm{X}_{\mathrm{i}}\end{array}$ & $\begin{array}{c}12 \\
92.3 \% \\
\end{array}$ & $\begin{array}{c}41 \\
83.7 \% \\
\end{array}$ & $\begin{array}{c}55 \\
85.9 \% \\
\end{array}$ & $\begin{array}{c}42 \\
84.0 \% \\
\end{array}$ & $\begin{array}{c}6 \\
85.7 \% \\
\end{array}$ & $\begin{array}{c}6 \\
85.7 \% \\
\end{array}$ & $\begin{array}{c}1 \\
100 \% \\
\end{array}$ & $\begin{array}{c}55 \\
84.6 \% \\
\end{array}$ & $\begin{array}{c}12 \\
80.0 \% \\
\end{array}$ & $\begin{array}{c}32 \\
91.4 \% \\
\end{array}$ & $\begin{array}{c}6 \\
66.7 \% \\
\end{array}$ & $\begin{array}{c}4 \\
100 \% \\
\end{array}$ & $\begin{array}{c}54 \\
85.7 \% \\
\end{array}$ \\
\hline & Total & $\begin{array}{c}\text { Count } \\
\text { \% within } \mathrm{X}_{\mathrm{i}}\end{array}$ & $\begin{array}{c}13 \\
100 \%\end{array}$ & $\begin{array}{c}49 \\
100 \%\end{array}$ & $\begin{array}{c}64 \\
100 \%\end{array}$ & $\begin{array}{c}50 \\
100 \%\end{array}$ & $\begin{array}{c}7 \\
100 \%\end{array}$ & $\begin{array}{c}7 \\
100 \%\end{array}$ & $\begin{array}{c}1 \\
100 \%\end{array}$ & $\begin{array}{c}65 \\
100 \%\end{array}$ & $\begin{array}{c}15 \\
100.0 \%\end{array}$ & $\begin{array}{c}35 \\
100 \%\end{array}$ & $\begin{array}{c}9 \\
100 \%\end{array}$ & $\begin{array}{c}4 \\
100 \%\end{array}$ & $\begin{array}{c}63 \\
100 \%\end{array}$ \\
\hline
\end{tabular}

$\mathrm{X}_{\mathrm{i}}$ : having grazing penalty, collaborating with the forest administration, quitting shepherd profession 
It was observed in the Sutculer district study area that the goat breeders in the age interval of 43-55 received more grazing penalties in comparison with the other age groups, that they are more inclined towards cooperation with the forest administration and that they do not want to quit this profession. It was also determined that the married goat breeders who continue this profession as a family received more grazing penalties in comparison with others but that they are always more inclined towards communication and cooperation with the forest administration. It was found that the individuals in this group do not want to quit the goat breeding profession.

Whereas it was observed in the Merkez district study area that goat breeders in the age interval of 31-42 received more grazing penalties and that they are not inclined towards cooperation with the forest administration. Some of the breeders in this age group stated that they are planning to quit this profession. It was also observed in this study area that the married goat breeders and those who continue this profession with their families were subject to more grazing penalties in comparison with others, that their levels of cooperation with the forest administration were low and that they do not want to quit this profession.

\section{Differences in the opinions of goat breeders in the two study areas}

Table 4 presents the Mann Whitney $U$ test results indicating the differences in opinion of the breeders in both districts with regard to the study variables. There are certain differences between the perspectives of Sutculer and Merkez district breeders regarding hair goat breeding and sustainable natural resource management. In other words, the Mann Whitney U Test (Table 4) results indicate that 15 out of the 30 opinions obtained from Sutculer and Merkez district breeders differ. Of these, the desire of the new generation to continue the breeding profession for hair goat breeding was higher in the Sutculer district in comparison with the Merkez district. The breeders in Sutculer district suffer more due to grazing penalties. The average grazing elevation for hair goats in Sutculer district was higher in comparison with the Merkez district. It is a common opinion in Sutculer district that the village headmen implement erroneous management applications with regard to the rangelands. While foreign breeders receive more grazing permits in the Merkez district, but this ratio is quite low in Sutculer district. It was observed with regard to the perspective on the management of sustainable natural resources that the capacity to cooperate with the forest administration is quite high in the Merkez district and that the goat breeders are more conscious in the Merkez district in preventing the harms given to trees and young saplings.

Goat breeders in the Merkez district study area request new grazing areas with higher quality from the forest administration. Therefore, it is necessary to provide new grazing areas especially in shrubberies. The goat breeders generally have a tendency to quit the breeding profession, however rural conditions do not present them with job opportunities other than agriculture and ovine breeding. In general, they do not want their children to continue this profession. The breeders in the Merkez district stated that they try to raise the awareness of their children for protecting the forests and nature. They stated that they plant various tree saplings from time to time at certain locations. The goat breeders in the Merkez district indicated that they warn the people harming the forests for a sustainable nature.

According to the Chi-Square Test of Independence, the variables from among the $\mathrm{X} 1, \mathrm{X} 2 ; \mathrm{X} 3, \mathrm{X} 4, \mathrm{X} 5, \mathrm{X} 6$ and X7 variables for the breeders in Sutculer and Merkez 
districts and other study variables for which there are statistically significant relationships are presented in Tables 5 and 6.

A statistically significant relationship was determined between the age parameter of the goat breeders in the Merkez district and their children continuing the breeding profession. Elderly breeders indicated that they do not want the new generation to continue this profession. Grazing was determined as a significant problem in this area as well. The environmental awareness of individuals who continue this profession as a tradition increases with increasing levels of education. Those who continue this profession as a family have more requests from the forest administration with regard to the conditions at the grazing areas. Those who have an additional income from professions other than goat breeding want to continue this profession at areas of lower elevation.

Table 4. Results of Mann Whitney U test

\begin{tabular}{|c|c|c|c|c|c|}
\hline Variables & $\begin{array}{l}\text { Mann-Whitney } \\
\text { U Value }\end{array}$ & $\begin{array}{l}\text { Asymp. Sig. } \\
\text { (2-tailed) }\end{array}$ & Variables & $\begin{array}{l}\text { Mann-Whitney } \\
\text { U Value }\end{array}$ & $\begin{array}{l}\text { Asymp. Sig } \\
\text { (2-tailed) }\end{array}$ \\
\hline $\mathrm{X} 1$ & 3250.00 & 0.55 & $\mathrm{X} 16^{*}$ & 2561.00 & $0.00^{\mathrm{a}}$ \\
\hline $\mathrm{X} 2$ & 2930.00 & 0.51 & $\mathrm{X} 17$ & 3313.50 & 0.57 \\
\hline $\mathrm{X} 3$ & 3251.50 & 0.44 & $\mathrm{X} 18^{*}$ & 2067.50 & $0.00^{\mathrm{a}}$ \\
\hline $\mathrm{X} 4$ & 2606.50 & 0.05 & X19 & 3134.50 & 0.23 \\
\hline $\mathrm{X} 5$ & 2827.00 & 0.12 & $\mathrm{X} 20^{*}$ & 2785.50 & $0.00^{\mathrm{a}}$ \\
\hline $\mathrm{X} 6$ & 3037.00 & 0.08 & $\mathrm{X} 21^{*}$ & 3028.50 & $0.00^{\mathrm{a}}$ \\
\hline $\mathrm{X} 7$ & 2449.50 & 0.10 & $\mathrm{X} 22$ & 3342.00 & 0.63 \\
\hline $\mathrm{X} 8^{*}$ & 2118.00 & $0.00^{\mathrm{a}}$ & $\mathrm{X} 23$ & 2476.00 & 0.08 \\
\hline$X 9^{*}$ & 2529.50 & $0.00^{\mathrm{a}}$ & $\mathrm{X} 24^{*}$ & 2451.50 & $0.00^{\mathrm{a}}$ \\
\hline $\mathrm{X} 10^{*}$ & 2487.50 & $0.00^{\mathrm{a}}$ & $\mathrm{X} 25^{*}$ & 2891.50 & $0.03^{\mathrm{a}}$ \\
\hline $\mathrm{X} 11$ & 2893.50 & 0.22 & $\mathrm{X} 26^{*}$ & 2743.00 & $0.03^{\mathrm{a}}$ \\
\hline $\mathrm{X} 12$ & 62.00 & 0.02 & $\mathrm{X} 27^{*}$ & 2792.00 & $0.03^{\mathrm{a}}$ \\
\hline $\mathrm{X} 13$ & 12.00 & 1.00 & $\mathrm{X} 28^{*}$ & 2277.50 & $0.00^{\mathrm{a}}$ \\
\hline X14 & 7.00 & 0.89 & $\mathrm{X} 29^{*}$ & 3187.00 & $0.04^{\mathrm{a}}$ \\
\hline $\mathrm{X} 15^{*}$ & 2199.50 & $0.00^{\mathrm{a}}$ & $\mathrm{X} 30^{*}$ & 2683.50 & $0.00^{\mathrm{a}}$ \\
\hline
\end{tabular}

${ }^{a}$ Asymp. Sig. (2-tailed) p $<0.05$

$* \mathrm{H}_{0}$ is rejected (shepherds in Merkez and Sutculer districts belong to the same community)

Table 5. Merkez district's chi-square independence test result

\begin{tabular}{c|c|c|c|c|c|c|c|c|c|c|c|c}
\hline \multicolumn{2}{l|}{} & $\mathbf{X 8}$ & $\mathbf{X 1 0}$ & $\mathbf{X 1 7}$ & $\mathbf{X 1 8}$ & $\mathbf{X 1 9}$ & $\mathbf{X 2 1}$ & $\mathbf{X 2 3}$ & $\mathbf{X 2 5}$ & $\mathbf{X 2 6}$ & X27 & X29 \\
\hline \multirow{2}{*}{ X1 } & Chi-Square Value & 17.8 & 17.2 & 11.01 & 6.98 & 20.1 & 9.27 & 3.10 & 17.9 & 10.6 & 20.1 & 36.8 \\
& Exact Sig. (2-sided) & $0.02^{\mathrm{a}}$ & 0.14 & 0.54 & 0.84 & 0.08 & 0.12 & 0.54 & $0.02^{\mathrm{a}}$ & 0.54 & $0.04^{\mathrm{a}}$ & 0.56 \\
\hline \multirow{2}{*}{ X2 } & Chi-Square Value & 6.78 & 5.99 & 16.49 & 1.98 & 1.42 & 6.18 & 0.14 & 8.16 & 6.25 & 10.71 & 6.45 \\
& Exact Sig. (2-sided) & 0.13 & 4.40 & $0.01^{\mathrm{a}}$ & 0.92 & 1.00 & 0.22 & 1.00 & 0.10 & 0.37 & 0.08 & 0.40 \\
\hline \multirow{2}{*}{ X3 } & Chi-Square Value & 7.02 & 14.5 & 10.7 & 12.68 & 10.66 & 71.0 & 2.37 & 24.9 & 29.04 & 18.8 & 45.9 \\
& Exact Sig. (2-sided) & 0.72 & 0.41 & 0.82 & 0.46 & 0.53 & $0.01^{\mathrm{a}}$ & 0.67 & 0.53 & $0.04^{\mathrm{a}}$ & 0.18 & $0.03^{\mathrm{a}}$ \\
\hline \multirow{2}{*}{ X4 } & Chi-Square Value & 21.48 & 8.06 & 13.51 & 10.78 & 17.6 & 7.36 & 18.34 & 17.88 & 11.00 & 12.05 & 25.86 \\
& Exact Sig. (2-sided) & $0.00^{\mathrm{a}}$ & 0.78 & 0.33 & 0.53 & 0.17 & 0.27 & $0.00^{\mathrm{a}}$ & $0.03^{\mathrm{a}}$ & 0.53 & 0.46 & $0.01^{\mathrm{a}}$ \\
\hline \multirow{2}{*}{ X5 } & Chi-Square Value & 3.79 & 4.95 & 1.48 & 11.3 & 8.40 & 0.12 & 4.14 & 9.61 & 2.03 & 9.11 & 8.41 \\
& Exact Sig. (2-sided) & 0.14 & 0.15 & 0.79 & $0.03^{\mathrm{a}}$ & 0.14 & 1.00 & 0.10 & $0.03^{\mathrm{a}}$ & 0.61 & $0.02^{\mathrm{a}}$ & 0.10 \\
\hline \multirow{2}{*}{ X6 6} & Chi-Square Value & 0.21 & 1.79 & 6.51 & 1.89 & 8.40 & 0.70 & 0.74 & 0.49 & 0.83 & 2.96 & 1.46 \\
& Exact Sig. (2-sided) & 0.93 & 0.66 & 0.10 & 0.73 & $0.01^{\mathrm{a}}$ & 1.00 & 0.43 & 0.85 & 0.83 & 0.42 & 0.40 \\
\hline \multirow{2}{*}{ X7 } & Chi-Square Value & 1.10 & 12.97 & 2.82 & 6.33 & 6.05 & 0.079 & 0.63 & 3.36 & 4.60 & 8.11 & 13.04 \\
& Exact Sig. (2-sided) & 0.66 & $0.01^{\mathrm{a}}$ & 0.48 & 0.12 & 0.12 & 1.00 & 0.41 & 0.22 & 0.14 & 0.06 & 0.14 \\
\hline
\end{tabular}

${ }^{\mathrm{a} E x a c t} \mathrm{Sig}$. (2-sided) $\mathrm{p}<0.0 ; \mathrm{H}_{0}$ is rejected 
Table 6. Sutculer district's chi-square independence test result

\begin{tabular}{c|c|c|c|c|c|c|c|c|c|c|c|c|c|c|c}
\hline \multicolumn{2}{l|}{} & X9 & X10 & X11 & X15 & X16 & X17 & X18 & X20 & X21 & X22 & X25 & X26 & X27 & X29 \\
\hline \multirow{2}{*}{ X1 1} & Chi-Square Value & 0.62 & 7.30 & 6.25 & 15.79 & 15.26 & 4.80 & 3.81 & 2.17 & 7.65 & 7.37 & 4.36 & 6.62 & 13.16 & 5.84 \\
& Exact Sig. (2-sided) & 0.89 & 0.29 & 0.40 & 0.14 & $0.17^{\mathrm{a}}$ & 0.99 & 0.70 & 0.99 & 0.56 & 0.29 & 0.64 & 0.69 & 0.15 & 0.44 \\
\hline \multirow{2}{*}{ X2 2 Chi-Square Value } & 1.51 & 7.80 & 10.22 & 17.76 & 4.02 & 4.25 & 1.56 & 12.19 & 35.25 & 9.73 & 1.10 & 4.83 & 10.83 & 7.26 \\
& Exact Sig. (2-sided) & 0.47 & 0.92 & 0.051 & $0.00^{\mathrm{a}}$ & 0.39 & 0.70 & 0.85 & 0.07 & $0.00^{\mathrm{a}}$ & $0.04^{\mathrm{a}}$ & 0.94 & 0.59 & 0.85 & 0.11 \\
\hline \multirow{2}{*}{ X3 } & Chi-Square Value & 12.85 & 39.08 & 11.34 & 12.09 & 12.01 & 16.91 & 8.40 & 28.69 & 17.95 & 12.32 & 8.55 & 14.57 & 21.57 & 6.68 \\
& Exact Sig. (2-sided) & $0.03^{\mathrm{a}}$ & $0.00^{\mathrm{a}}$ & 0.33 & 0.26 & 0.22 & 0.47 & 0.64 & 0.09 & 0.23 & 0.25 & 0.48 & 0.50 & 0.10 & 0.59 \\
\hline \multirow{2}{*}{ X4 } & Chi-Square Value & 0.23 & 25.97 & 15.34 & 25.69 & 10.75 & 16.15 & 10.94 & 37.33 & 23.42 & 12.65 & 6.27 & 15.58 & 21.43 & 6.73 \\
& Exact Sig. (2-sided) & 1.00 & 0.05 & 0.85 & $0.00^{\mathrm{a}}$ & 0.20 & 0.40 & 0.19 & $0.00^{\mathrm{a}}$ & 0.11 & 0.11 & 0.57 & 0.20 & $0.04^{\mathrm{a}}$ & 0.49 \\
\hline \multirow{2}{*}{ X5 } & Chi-Square Value & 1.45 & 13.45 & 17.99 & 2.69 & 7.02 & 12.86 & 7.47 & 16.37 & 7.85 & 0.70 & 21.61 & 4.09 & 8.70 & 3.35 \\
& Exact Sig. (2-sided) & 0.32 & $0.02^{\mathrm{a}}$ & $0.00^{\mathrm{a}}$ & 0.38 & $0.04^{\mathrm{a}}$ & $0.00^{\mathrm{a}}$ & $0.01^{\mathrm{a}}$ & $0.01^{\mathrm{a}}$ & 0.09 & 0.85 & $0.00^{\mathrm{a}}$ & 0.25 & $0.02^{\mathrm{a}}$ & 0.21 \\
\hline \multirow{2}{*}{ X6 6} & Chi-Square Value & 5.38 & 3.15 & 2.00 & 1.48 & 0.42 & 4.84 & 1.28 & 2.68 & 4.07 & 1.31 & 0.52 & 10.53 & 5.53 & 1.69 \\
& Exact Sig. (2-sided) & $0.02^{\mathrm{a}}$ & 0.2 & 0.34 & 0.47 & 0.88 & 0.31 & 0.55 & 0.47 & 0.25 & 0.53 & 0.81 & $0.01^{\mathrm{a}}$ & 0.14 & 0.60 \\
\hline \multirow{2}{*}{$\mathrm{X} 7$} & Chi-Square Value & 0.54 & 17.17 & 15.82 & 7.87 & 3.11 & 3.62 & 2.08 & 37.82 & 38.03 & 8.41 & 3.42 & 2.55 & 10.99 & 11.86 \\
& Exact Sig. (2-sided) & 0.58 & $0.00^{\mathrm{a}}$ & $0.00^{\mathrm{a}}$ & $0.02^{\mathrm{a}}$ & 0.24 & 0.43 & 0.37 & $0.00^{\mathrm{a}}$ & $0.00^{\mathrm{a}}$ & $0.01^{\mathrm{a}}$ & 0.22 & 0.46 & $0.01^{\mathrm{a}}$ & $0.01^{\mathrm{a}}$ \\
\hline
\end{tabular}

${ }^{a}$ Exact Sig. (2-sided) $\mathrm{p}<0.0, \mathrm{H}_{0}$ is rejected

Young goat breeders in Sutculer district are of the opinion that the village rangelands are managed erroneously and do not approve of the grazing permits provided for their own regions to breeders from other districts. It was determined that goat breeders with lower education levels are subject to more grazing penalties. Breeders involved in this profession for shorter periods of time are of the opinion that the village rangelands are managed erroneously. It was observed that goat breeders with means of income other than goat breeding graze their goats at lower elevations, follow up state aids and display more sensitive behaviors towards the environment.

The variables with a statistically significant relation between them are indicated in bold in Tables 5 and 6 .

The results for the Sutculer district Multivariate Linear Regression Analysis carried out via Stepwise method are presented in Table 7. However, the $\mathrm{R}^{2}$ levels were calculated to be very low (below 30\%) in the Merkez district Multivariate Linear Regression Analysis carried out via stepwise method and hence the acquired results were not tabulated.

Table 7. Multivariate regression analysis result of Sutculer district

\begin{tabular}{|c|c|c|c|c|c|c|c|c|c|c|c|c|c|c|c|c|}
\hline \multirow{3}{*}{$\begin{array}{c}\text { Dep. } \\
\text { variables }\end{array}$} & \multirow{3}{*}{ Model } & \multirow{3}{*}{$\mathbf{R}^{2}$} & \multirow{2}{*}{\multicolumn{2}{|c|}{ Anova }} & \multirow{2}{*}{\multicolumn{2}{|c|}{ Constant }} & \multicolumn{10}{|c|}{ Dependent variables } \\
\hline & & & & & & & \multicolumn{2}{|c|}{ X1 } & \multicolumn{2}{|c|}{$\mathbf{X 3}$} & \multicolumn{2}{|c|}{$\mathrm{X} 4$} & \multicolumn{2}{|c|}{ X6 } & \multicolumn{2}{|c|}{$\mathrm{X} 7$} \\
\hline & & & $\mathbf{F}$ & Sig. & Beta & Sig. & Beta & Sig. & Beta & Sig. & Beta & Sig. & Beta & Sig. & Beta & Sig. \\
\hline \multirow{2}{*}{$\mathrm{X} 18$} & 1 & 0.10 & 5.61 & 0.02 & 0.88 & 0.00 & & & & & & & & & 0.36 & 0.02 \\
\hline & 2 & 0.20 & 6.19 & 0.00 & 0.34 & 0.00 & 0.17 & 0.01 & & & & & & & 0.38 & 0.01 \\
\hline $\mathrm{X} 20$ & 1 & 0.08 & 4.54 & 0.03 & 0.68 & 0.00 & & & & & & & 0.46 & 0.03 & & \\
\hline \multirow{3}{*}{$\mathrm{X} 21$} & 1 & 0.16 & 10.49 & 0.00 & 1.24 & 0.00 & & & -0.08 & 0.00 & & & & & & \\
\hline & 2 & 0.44 & 20.02 & 0.00 & 1.69 & 0.00 & & & -0.11 & 0.00 & -0.067 & 0.00 & & & & \\
\hline & 3 & 0.49 & 16.26 & 0.00 & 1.75 & 0.00 & -0.05 & 0.00 & -0.11 & 0.00 & -0.050 & 0.00 & & & & \\
\hline $\mathrm{X} 26$ & 1 & 0.09 & 5.84 & 0.19 & 1.24 & 0.00 & & & & & & & 1.08 & 0.019 & & \\
\hline $\mathrm{X} 27$ & 1 & 0.24 & 16.05 & 0.00 & 0.75 & 0.00 & & & & & & & 0.25 & 0.00 & & \\
\hline X30 & 1 & 0.19 & 12.05 & 0.00 & & & & & & & & & 0.20 & 0.00 & & \\
\hline
\end{tabular}


The specificity coefficient $\left(\mathrm{R}^{2}\right)$ level in regression models that explain the change in the dependent variables of the Sutculer district in a statistically significant manner was calculated as $44-49 \%$ for the X21 dependent variable and as lower than $25 \%$ for the other dependent variables. Hence, only the regression equalities for the "Expelling treeharming animals from the forest" dependent variable can be used for estimation. Therefore, there is a need for other variables to estimate the related dependent variables for the Sutculer and Merkez districts breeders.

\section{Conclusions}

It was observed upon evaluating the results related with the general characteristics of goat breeding businesses that the breeders are generally above middle age and that they do not want their children to continue this profession. The education levels of current goat breeders were determined to be quite low. In light of these findings, it can be estimated that traditional goat breeding profession will decrease at a rapid rate in the coming years. The most important problem of goat breeders was determined to be grazing issue and a solution for this problem should be developed in cooperation with the forest administration. Of the goat breeders, $21 \%$ in the first study area and $45 \%$ in the second study area were subject to fines due to unauthorized grazing in forest resource areas. This is an important finding of the study and it can be stated that goat breeders make certain violations with regard to sustainable forest resources management due to the grazing problem they face. Hence, the cooperation between goat breeders and forest administrators should be increased to provide solutions to this issue.

It was determined that the interventions by goat breeders in the Sutculer district for preventing the goats from harming the trees in the forest during grazing decreased with increasing age, decreasing education level and the duration of experience in this profession (Table 7).

According to the study results, the two rural settlement areas are not similar with regard to characteristics related to demographic-socioeconomic and hair goat breeding as well as sustainable management of forests even though they are located in the same geographical region. Therefore, it is not sufficient to only consider geographical area similarity when determining the precautions for preventing breeders from harming the forests or in other words the precautions for enabling them to contribute to the sustainable management of forests. In addition, it was observed that especially age, education level and the duration of experience in breeding are variables that should be taken into consideration with regard to precautions for increasing the participation of breeders in the sustainable management of forest resources.

Acknowledgments. This study was supported by the Turkish Scientific and Technical Research Council of Turkey (TUBITAK) (Project No: 117O549). The authors extend their gratitude to the TUBITAK.

Conflict of interests. The authors declare that there is no conflict of interests regarding the publication of this paper. 


\section{REFERENCES}

[1] Ainalis, A. B., Tsiouvaras, C. N. (2004): Forage production of woody fodder species and herbaceous vegetation in a silvopastoral system in Northern Greece. - Agroforestry Systems, 42: 1-11.

[2] Ainalis, A. B., Tsiouvaras, C. N., Nastis, A. S. (2006): Effect of summer grazing on forage quality of woody and herbaceous species in a silvopastoral system in Northern Greece. - Journal of Arid Environment 67: 90-99.

[3] Aldezabal, A., Garin, I. (2000): Browsing preference of feral goats (Capra hircus L.) in a Mediterranean mountain scrubland. - Journal of Arid Environment 44: 133-142.

[4] Arac, B., Daskiran, I. (2010): Diyarbakır ili keçicilik işletmelerinin yapısal özellikleri (Structural Characteristics of Goats in Diyarbakir Province). - Journal of Tekirdag Agricultural Faculty 3(7).

[5] Bassullu, C., Tolunay, A. (2010): Analysis on traditional homegarden involving animals practices and its importance classification of usage purposes in rural areas of Isparta region of Turkey. - Asian Journal of Animal Veterinary Advances 5: 450-464.

[6] Bekiroğlu, S., Özdemir, M., Özyürek, E., Arslan, A. (2016): Opportunities to enhance contribution of model forests in the sustainable forest resources management (example from Yalova Model Forest). - Journal of Environmental Management 181(1): 701-709.

[7] Boyazoglu, J., Hatziminaoglou, I., Morand-Fehr, P. (2005): The role of the goat in society: past, present and perspectives for the future. - Small Ruminant Research 60: 1323. https://doi.org/10.1016/j.smallrumres.2005.06.003.

[8] FAO (1991): The State of Food and Agriculture 1991. - FAO Agriculture Series, no. 24, Rome.

[9] Gholz, H. L. (1986): Canopy Development and Dynamics in Relation to Primary Production. - In: Fujimori, T., Whitehead, D. (eds.) Crown and Canopy Structure in Relation to Productivity. Proc. Int. Workshop, October 1985, Ibraki, Japan, pp. 224-242.

[10] Guney, O., Darcan, N. (2001): Süt keçiciliğinde ileri tekniklerin uygulanabilirliği için gerekli koşullar (Necessary conditions for applicability of advanced techniques in goat milk production). - Goat Cultivation Panel in Canakkale Province, 12 June, Canakkale, Turkey.

[11] Guney, O., Darcan, N. (2005): Akdeniz kuşağında keçi yetiştiriciliğinin yapısal durumu ve gelişme perspektifleri (The structural status and development perspectives of goat cultivation in the Mediterranean Zone). - International Symposium on Forest, Goat, Erosion and Tourism, 12-13 April 2005, Adana, Turkey.

[12] Heitschmidt, R. K., Taylor, C. A. (1993): Livestock Production. - In: Heitschmidt, R. K., Stuth, J. W. (eds.) Grazing Management: An Ecological Perspective. Timber Press, Portland, OR, pp. 161-177.

[13] Heitschmidt, R. K., Dowhower, S. L., Walker, J. W. (1987): Some effects of rotational grazing treatment on quantity and quality of available forage and amount of ground litter. - J. Range Manage. 40: 318-321.

[14] Ince, D. (2010): Reproduction performance of Saanen goats raised under extensive conditions. - African Journal of Biotechnology 9(48): 8253-8256.

[15] Ince, D., Karaca, O. (2009): Effects of oestrus synchronization and various doses of PMSG administration in Chios $\times$ Kivircik (F1) sheep on reproductive performances. Journal of Animal Veterinary Advances 8: 1948-1952.

[16] Ince, D., Koknaroglu, H., Toker, M. T. (2009): Sustainability suggestions for goat husbandry in Isparta, Turkey. - Macedonian Journal of Animal Science 2(2): 133-138.

[17] Karasar, N. (2012): Scientific Research Method: Concepts, Principles, Techniques. Nobel Press, Ankara.

[18] Kasikci, D. (2016): Grazing in forests. - Isparta Province Pasture Workshop, 09-10 March 2016, Isparta, Turkey. 
[19] Kıvrak, R. (2014): Walking Turks Nomadics (Yürüyen Türkler Yörükler). - Ege reklam basım sanatları San. Tic. Ltd., Şti. İzmir.

[20] Koknaroglu, H., Ali, A., Ekinci, K. Morrical, D. G., Hoffman, M. P. (2007): Cultural energy analysis of lamb production in the feedlot or on pasture and in the feedlot. Journal of Sustainable Agriculture 30: 95-108.

[21] Koyuncu, M., Tuncel, E. (2010): Keçinin Önemi ve Yörük Kültüründeki Yeri (Importance of goat and its place in nomadic culture). - Uludağ University Agricultural Faculty, Zootechnology Department, National Congress on Goat Cultivation, Bursa, Turkey.

[22] Laugesen, M., Elliot, R. (2003): Ischaemic heart disease, Type 1 diabetes, and cow milk A1 ß-casein. - New Zealand Medical Journal 116(1168): U295.

[23] Morand-Fehr, P., Boutomet, J. P., Devendra, C., Dubeuf, J. P., Haeinlein, G. F. W., Holst, P., Mowlem, L., Capote, J. (2004): Strategy for goat farming in the 21st century. - Small Ruminant Research 51: 175-183.

[24] Sample Size Calculator (2018): https://www.surveysystem.com/sscalc.htm.

[25] Schmincke, K. H. (1995): Forest industries: crucial for overall socio-economic development. - Unasylva-No.182-FAO 50th anniversary. http://www.fao.org/3/v6585e/V6585e00.htm\#Contents.

[26] Semerci, A., Çelik, A. D. (2016): Türkiye'de küçükbaş hayvan yetiştiriciliğinin genel durumu. (Small Ruminant Breeding in Turkey). - Mustafa Kemal Üniversitesi Ziraat Fakültesi Dergisi 21(2): 182-196.

[27] Ocak, S., Torun, O., Guney, O. (2007): A novel method of analyzing rearing system on lamb growth and farm profitability. - African Journal of Agricultural Research 6: 495499.

[28] Ocak, S., Davran, M., Guney, O. (2010): Small ruminant production in turkey: highlighting in goat production. - Tropical Animal Health and Production 42(2): 155159.

[29] Tasligil, N., Sahin, G, (2010): Türkiye'de Keçi Yetiştiriciliğinin Coğrafi Dağılımı (Geographical Distribution of Goat Breeding in Turkey). - Ulusal Keçicilik Kongresi (National Congress on Goat Cultivation, 24-26 June, Çanakkale, Turkey.

[30] Tolunay, A., Alkan, H., Korkmaz, M. (2002): Bat1 Akdeniz Bölgesi'nin Agroforestry (Tarımsal Ormancilı) Üretim Potansiyeli (Agroforestry (Agricultural Forestry) Production Potential in the Western Mediterranean Region). - Office for Research Projects Management, University of Suleyman Demirel. Project No: 275, Isparta, Turkey.

[31] Tolunay, A., Ayhan, V., Adiyaman, E., Akyol, A., Ince, D. (2009): Herbage growth and fodder yield characteristics of kermes oak (Quecus coccifera L.) in a vegetation period. Journal of Animal and Veterinary Advances 8(2): 290-294.

[32] Tolunay, A., Babalik, A., Yavuz, M., Akyol, A., Kasikci, D., Adiyaman, E. (2015): Keçi Orman Çelişkisinde Son Durum: Ne Yapıldı? Ne Yapılıyor? Ne Yapılmalı? (Contradiction between Goat and Forest: What was done? What is being done? What should be done?) - Orman ve Av Dergisi (Journal of Forest and Hunt) 6(2): 24-29.

[33] Tolunay, A., Ince, D., Daskiran, I., Turkoglu, T., Ozmis, M. (2018): Role of Goat Breeding in Reducing Rural Poverty in the Western Mediterranean Region of Turkey. 1st International Symposium on Silvopastoral Systems and Nomadic Societies in Mediterranean Countries, 22-24 October 2018, Isparta, Turkey.

[34] Zarovali, M. P., Yiakoulaki, M. D., Papanastasis, V. P. (2007): Effects of shrub encroachment on herbage production and nutritive value in semi-arid Mediterranean grasslands. - Grassland Forage Science 62: 355-363. 